\title{
Mechanisms to Eradicate Child Labour among School Children in the Kete-Krachi Area
}

\author{
YEYIE PATRICK
}

\begin{abstract}
In Ghana, about $20 \%$ of school children are involved in some form of child labour. In the Oti Region of Ghana, the Kete-Krachi district has the highest prevalence rate of about 39 percent compared to 33.2 percent for the whole region (Volta Region, 2007). This article seeks to suggest various mechanisms to be used to eradicate the menace among the Junior High School students in the Kete-Krachi district of the Oti Region to bring about better academic performance of the students. The study interviewed 145 respondents through questionnaire and interviews. The research design for the study was both quantitative and qualitative. The respondents comprised $60 \mathrm{JHS}$ teachers, 60 Victims of child labour, 15 parents or guardians of the victims of child labour and 10 stakeholders of education. Data analysis shows that teachers, opinion leaders, NGOs and the Government have a role to play in the eradication of child labour in the Kete-Krachi area.
\end{abstract}

Keywords Eradicate, mechanism, control and school children

DOI: $10.7176 /$ RHSS/10-14-06

Publication date:July $31^{\text {st }} 2020$

\section{Introduction}

Child labour is a Widespread and growing phenomenon. It has been a common practice for a long time. It has become a matter of grave concern over the past decade especially in the developing countries. The ILO in 1995 estimated that about 250 million children between the ages of S and 14 in developing countries alone were used as child labour (UNICEF, 2002; Donnellan, 2002). Therefore it has become a focus of attention in the international arena especially by children's rights activists.

However, there seems to be controversy on the nature of child labour. First, there is lack of agreement on what activity and at what stage an activity constitutes child labour. Second, the meaning of child labour varies from society to society and from culture to culture. These give much problem to the implementation of UN conventions on the problem. Some individuals and organizations define the term as work children do in order to earn incomes or to the benefit of somebody else, while others concede that such an activity should affect the child one way or the other (Children Rights Convention, 1989; UNICEF, 2001; Kelsey \&Peterson, 2003). The ILO (2004) and Children's Act 560 (1998) of Ghana proposed a minimum age of 15 for normal work and a minimum age of 18 for hazardous work. Other writers such as Canagarah and Colombes (1993), Jensen and Neilson (1997) and Jean-Marie and Robinson (2000) saw child labour as employment of children who are not in school should be free and compulsory at least at the elementary level. Article 30 of the same declaration required all member nations to ensure that no person was engaged in any activity destructive to his or her rights.

In 1959, the UN General Assembly adopted the Declaration of the rights of the child. This reaffirmed the declaration of free and compulsory elementary education as well as the protection of children from exploitation.

On 16th December, 1966, the UN General Assembly adopted the International Covenant on Economics, Social and Cultural Rights, which provided specific protection against child labour. Article 10(3) of this Covenant stated that "children should be protected from economic and social exploitation. It further indicated that employment of children in work which was harmful to their education, health and development should be punished by law and that the state should provide appropriate age for the employment of young people." It once again reaffirmed the declaration of free and compulsory primary education.

The UN declared 1979 as the International Year of the Child to reaffirm the protection of the child especially against exploitative child labour. On 20th November 1989, the UN General Assembly approved the Convention on the Rights of the Child which was ratified on 2"d September 1990. Within the preambles of the convention, special references were made to the 1948 Declaration of Human Rights, the 1959 Declaration of the Rights of the child and Article 10 of the International Covenant on Economic, Social and Cultural Rights which sought to protect the child. Article 32 of this convention specifically talked on child labour. Clause one of these Articles stated that the child should be protected from economic exploitation and from performing any works that was likely to be hazardous or interfere with the child's education.

Notwithstanding these global efforts, the prevalence rate is rather high in developing countries, especially Africa, which has the highest incidence of child labour. An estimate of the International Labour Organization (ILO) in 1995 indicated that 41 percent of all African children between 5-14 years were involved in some form of economic activities which could be described as child labour. This compares with 21 percent in Asia and 17 percent in Latin America (Africa Recovery 2001). The socio economic set up in Africa contributes to the high prevalence rate of child labour. 
Most parents in Africa lack formal education and are self-employed. Children therefore receive training on how to work by participating in the work their parents or guardians do. The large family size in most African communities also contributes to the poverty situation aggravating the high prevalence rate (UNICEF, 1992). In Ghana, for instance, about 25 percent of the population is extremely poor, with per capita less than USS 280 (UNICEF, 2004). Children are therefore compelled to work at a tender age to supplement family income. It has been estimated that there are about 80 million child workers across Africa; a number that could reach 100million by 2015 as a result of poverty (UNICEF .2009). The cultural set up in Africa also serves as impediment for the implementation of polices on child labour. For example, it is not expected or easy for a child to report his or her parents for abusing his or her rights. This encourages the employment of children in work. There is also lack of political will on the part of most African government to implement policies on child labour. Most of them concentrate only on how they can continue to remain in the power forever and this leads to the neglect of problems like child abuse which do not threaten their political future (IPEC, 2003).

A base line study commissioned by the Ghana Government in 2007 revealed that 6.3 million children were victims of child labour, (Daily Graphic, 4, 2007) as against 1.2 million in 2003 which was observed by Global Watch International Secretariat, (2004). Most working children in Ghana (about 82.5\%) in 1992 were found in the rural areas, mostly involved in agricultural activities. The worse form of child labour in Ghana includes mining and stone quarrying, fishing, galamsey operations, and porter age of heavy load, commercial farming and commercial sex work ( Children's Act 560-1998;

Daily Graphic, Friday, May 4, 2007). It is common in Ghana to see children below age 15 engaged in such activities. The problem however is that most of such victims are children of school going age (Kim \& Kantor, 2005; Stranrock, 2005). These children are forced to give up benefits of education in order to provide the immediate gains associated with child labour because of their economic and other social circumstances. Child labour therefore has been a major constraint in the development of human capital in Ghana. Governments since independence have tried measures aimed at eliminating it and promoting the development of human capital. Postindependence efforts to eliminate child labour started with the education Act 87 (1961) which made education free and compulsory for all children of school going age (UNICEF, 2004). In 1967, the Ghana's labour decree (I967) prohibited employment of children under the age of 15. Other post-independence measures included the free and compulsory basic education in the 1987 education reforms, the ratification of the UN Convention on children's rights, Article 28 (2) of the 1992 constitution, the Free Compulsory Universal Basic Education (FCUBE) in 1996 and the Children Act (1998). In addition, in 2001 the Government instituted the capitation grant to reduce burden of parents and enhance children's education. The grant provides three Ghana cedis to cover the essential school fees of school at the basic level such as text book, fees, cultural fees and sport fees. Another programme to reduce the burden of parents is the School Feeding Programme (SFP) which is currently in the pilot stage. Despite the above efforts by the Government of Ghana, child labour is still a common phenomenon in the Volta Region $(33.2 \%)$, with the Kete-Krachi district being the highest (39.1\%). (htt ://www.Modem:hana.com/GhanaHome/re:ions.volta.ase?). As a rural District most of the children are engaged in agricultural activities such as processing of cassava into gari and maintenance of farms. This is affecting the development of the human capital of the district. The district has the highest rate of illiteracy $(70.2 \%)$ compared to 41.7 for the Volta region and $42.1 \%$ for the nation (Kete-Krachi District Assembly, 2006). This is dragging the development of the district back. Child labour among school children might be a contributory factor for the low enrollment and poor academic performance in most of the schools in the district.

\section{Statement of the problem}

Some school children in Kete-Krachi area are victims of child labour. Consequently, they are made to perform work such as fishing, farming, quarrying and carting of heavy loads. Socio-cultural and economic situations such as poverty, polygamous marriages, cultural beliefs and high number of households push the children to work at a tender age. They face multiple burdens such as tiredness, lateness to school, and poor performance in school and drop out from the numerous activities they do. The lifelong damage to the children include denying them basic literacy and vocational skills as well as psychological and physical trauma. It deprives the victims of a better future life and this leads to vicious cycle of poverty. There is however, very little knowledge about the mechanism to eradicate the menace to pave way for better academic performance of the students in the area.

\section{Scope of the study}

The research area was the Kete-Krachi District of the Oti Region. The Krachi District was selected based on one issue. That is, even though child labour appears to be high, no research seems to have been carried out in the area to provide baseline mechanism to eradicate it. The study covered students (JHS) in the area because they are often used as victims of child labour. They constitute the age group (12-15years) within which child labour is rampant. Their teachers and parents were also involved in the study. Even though, child labour might also be common among the primary school children, such children might not be able to provide relevant information. Hence the 
JHS children who were more matured were used. The study investigated the various mechanisms to be used to eradicate the menace for better academic performance of the students.

\section{LITERATURE REVIEW}

This chapter reviews related literature on the mechanism to eradicate child labour. The literature includes the most current knowledge about the problem. It also provided guidelines for fieldwork and interjections of the research findings and theoretical framework.

\section{Mechanisms to eradicate child labour}

Mechanisms to eradicate child labour started in the 19th century when Britain and Germany passed child labour laws in 1802 and 1839 respectively. The US also passed a law on child labour that failed in 1916 (World Bank Encyclopedia Vol.3 1992). These laws sought to prohibit employment of children below 18 years. There have also been many attempts by the UN to abolish child labour. One of such attempts was the adoption of the Universal Declaration of Human Rights by the General Assembly in 1945. Article 26(1) of the Declaration stated that everyone has the right to education and education shall be free and compulsory at least in the elementary and fundamental stages. It was of the view that by making education free and compulsory, child labour would be eradicated. Article 26(2) of the same Declaration stated that, it is through education that rights and fundamental freedoms would be strengthened and achieved. Article 30 provided a warning to member states never to engage any person in an activity that was destructive to his or her rights. (UNICEF, 2004). In 1959, the UN also adopted the Declaration of the rights of the Child. This forms the basis for the celebration of International Year of the Child in 1979 (Mensah-Bonsu \& Dowuona-Harmon, 1994). The international Covenant on Economic, Social and Cultural Rights (ICESCR) was also adopted by the UN General Assembly on 16th December, 1966 to address human rights. Article 10(3) of the Covenant stated that special measures of protection and assistance should be taken on behalf of all children and young people without any discrimination for reasons of parentage or other conditions. It continued that, children and young people should be protected from economic and social exploitation. Their employment in work is harmful to their morals or health or dangerous to their life or likely to hamper their normal development should be punishable by law and states should set age limits below which the paid employment of labour should be prohibited by law. (Http: www.UN.org. /over/rights.htm. 6-5-10) The most recent mechanism and a guiding document worldwide for the protection of children in general and eradication of child labour in particular has been the convention on the Rights of the Child. It was approved by the UN General Assembly on 20th November, 1989 and was ratified on 2nd September. Article 32 of this convention specifically talked about work condition of children and child labour. Clause one of this article indicated that states should ensure that the child is "protected from economic exploitation and from performing any work that is likely to be hazardous or interfere with the child's education or to be harmful to the child's health or physical, mental, spiritual, moral or social development" (Convention on the Rights of the Child: 44). Clause 2 of the same article like its counterpart in 1966, tasked states to provide a minimum age for admission to employment, appropriate regulations of the hours and conditions of employment and effective penalties against laws of child labour. Other bodies of the UN such as ILO, IPEC, UNICEF and UNESCO provide a lot of mechanism for the eradication of child labour. The ILO for instance proposed that the minimum age for work should not be less than 13 years whilst the minimum age of employment of children in normal work should not be less than 15 years. It further stated that, employment of people into hazardous work should not be less than 18 years (IPEC, 2003, ILO, 2004). UNICEF and UNESCO have been organizing programmes aimed at ensuring children's welfare and eliminating child labour. The Dakar Framework for Action (UNESCO, 2000) came out with a proposal. Some important articles geared towards elimination of child labour included Article 3 and 7. Article 3(2) for instance stated that, commitment must be made to remove all forms of child labour whilst that of 7(2) stated that each member state should take measures to prevent the engagement of children in the worst forms of child labour and ensure their access basic education. They tasked member states to establish child labour offices in their various communities. The African Union (AU) has also been much concerned about the welfare of children. It came out with a Charter on the Welfare and Rights of the Child in 1990 but entered into force in November 29, 1999. Article 3 tasked member states to provide free and compulsory basic education and take measures to encourage regular attendance in the schools and the reduction of drop-out rates. Article 15 of the Charter specifically dwelled on child labour. It stated the following: 1. Every child shall be protected from all forms of economic exploitation and from performing any work that is likely to be hazardous or to interfere with the child's physical, mental, spiritual, moral or social development.

2. State Parties to the present, charter shall take all appropriate legislature and administrative measures to ensure the full implementation of this article which covers both the formal and informal sectors of employment and having regard to the relevant provisions of the International Labour Organizations instruments relating to children.

States parties shall in particular:

a) Provide through legislation, minimum ages for admission to every employment;

b) Provide for appropriate regulation of hours and conditions of employment, 
c) Provide for appropriate penalties or other sanctions to ensure the enforcement of this article;

d) Promote the dissemination of information on the hazards of child labour to all sectors of the community.

(http://www umn.edu/humarts/africa/afchild. htm)

In Ghana, the Government has shown more commitment to the issues of child labour. She became the first to rectify the convention on the Children's Rights in 1990. The GNCC was quickly established in 1991 to address issues in the convention. To make child labour part of the statute book, it was incorporated into the 1992 constitution. Article 28(2) of the 1992 constitution stated that "Every child has the right to be protected from engaging in work that constitutes a treat to his health, education or development". (1992 Constitution: 25). The children's Act 560 (1998) of Ghana was designed to show more commitment on the part of Government of Ghana to protect the right of the child. The Act made the following provisions for the prohibition of child labour. Article 67(1) stated that "No person shall engage a child in exploitative labour". Whilst clause (2) explained exploitative child labour as the labour of a child that deprives him or her of health, education or development. Article 88(1) further stated that "No person shall engage a child in night work" and Article 89 gave the minimum age for admission of a child to employment to be fifteen years. (Children's Act, 1998:27). With these national and international conventions, what is needed is public education and monitoring strategies. Government authorities, rights activists, expect and community leaders must educate parents and guardians about the dangers of child labour (Africa Recovery, 2001).The laws must also be enforced. Government must set severe punishments for people who engaged in child labour (Daily Graphic, May 4 \& May 7 2007).

Ghana Statistical Service (2003) provided the following as recommendations for the elimination of child labour.

$>$ The major reason why children are not attending school is affordability. The government should fully implement the Free and Compulsory Universal Basic Education (FCUBE) to make education more accessible to poor households.

$>$ The Children's Act of 1998 must be reviewed to incorporate legislation on a maximum number of hours a child under 25 years of age could be engaged beyond which he or she would be said to be exploited. The Ghana Child Labour Survey (GCLS) recommended 4 hours.

The Children's Act should be enforced and made fully operational. Legal and judicial practitioners, the police and other law enforcement agencies must be educated on the Act and sensitized on child labour issues. There should be a programme to educate parents, teachers and the general public on the relevant sections of the Act. The Department of Social Welfare should be supported in terms of staff and logistics to effectively monitor child labour programmes in the country. The Ghana Child Labour Survey report must be widely disseminated by the ministry of Manpower Development and employment and Ministry of Women and Children Affairs as well as dialogue with Parliamentarians and other policy makers to educate them on the problem. Teachers can play a major in the elimination of child labour. "As part of their regular work, teachers use formal and informal mechanisms to keep an eye on children's absenteeism from school and identifying children at risk of dropping out of school and responding to this risk. It is through this process which is an integral part of a broader Child Labour Monitoring (CLM) strategy that teachers can support efforts to eliminate child labour" (IPBC, 2003:11). The same source contended that CLM is a strategy and active tool to identify child laborers and the risk to which they are exposed to. While CLM involves a more detailed programme of identification, prevention, withdrawal and tracking, teachers could play their part by being involved in the monitoring and identification process through the very nature of their day-to-day work in schools and by strengthening the capacity of communities to combat child labour. Setting up Child Labour Monitoring System (CLMS) involves a broad base alliance of partners (trade unions, teachers and employers' organizations, NGOs parents and community based groups). As part of this process, School Inspection System (SIS) also cold monitor school entry, attendance and completion of child laborers.

The support of parents and communities is essential in the fight against child labour. By being sensitized to the dangers children face and by getting involved in child labour activities, parents and community can do much to bring an end local child labour practices and ensure that children received a basic education that met their needs (ILO, 2004; IPEC, 2003). It is in this direction that District Chief Executive of South Tongu appealed to community leaders, chiefs and parents to partner the district assembly to eradicate the problem of child labour (The Mirror, Saturday July 19, 2008). The challenge of combating child labour requires the concerted efforts of a number of key players. These include the UN, Government institutions, teachers, trade unions, NGOs, Community leaders, parents and individuals (ILO, 2004). However, the key player among these institutions, the UN, lacks the constabulary power to compel its member states to implement conventions and regulations on child labour they have all agreed to implement. Governments in the various countries should therefore, provide the constabulary power to enforce laws and policies on child labour.

\subsection{Theoretical Framework}

There is a growing body of knowledge concerning the causes and consequences of child labour. A classical work 
by Brown, Deardorff and Stern (2001), provides theories on child labour which may serve as a model for this study. Brown, et a]. stated that it is a commonly held view that child labour is fundamentally a by-product of poverty, thus strongly suggesting that policy should focus on economic development and increasing income. If this was true then efforts to reduce child labour in developing countries would not gain grounds because the process of economic development has been very slow in the last decade. Therefore, more efforts should be made on other major causes distinct from poverty. That is, policies of government in the developing countries should be focusing more on creating job opportunities for the people to eliminate child labour. When the people are employed, they would be able to earn regular income which would enable parents send and keep their children in school. This would go a long way to help check child labour and its related problems that affect child education in the country.

Brown et al. (2001) took a departure from the poverty syndrome. They argued that one major cause of child labour is the household decision. Here, parents may view children in terms of their value as assets. Parents first choose the number of children to have. They argued further that parents who choose a large number of children are less likely to invest in quality schooling. Parents may also choose to have a large number of children in order to diversify risk, formally educating some and putting others to work .Children from large families in both developed and developing countries benefit less from schooling and tend to forfeit formal education.( Deardorff \& Stern, 2001) With large number of children available to engage in household, the opportunity cost of education for one child may be quite low. Large family size therefore account for child labour in most societies. This is relevant to this study because in Ghana, and for that matter Kete-Krachi area, apart from poverty, child labour can be caused by large families. Polygamous marriage which is commonly practiced in the area may result in large family size which in turn could result in child labour. In making child employment decision, parents weigh the present discounted value of the future income of an educated child against the forgone income while the child was in school. Child labour was only chosen if the return was not high enough to compensate families for the loss of income of children. The return to education for a poor child was lower than for children generally. The low return to education for the poor children would occur if schools were far away, inadequately staffed, and lacked educational supplies or materials. The return to education could also simply be unappreciated if parents themselves were not educated. Parents could also make a decision to borrow against the household future wealth to increase current consumption while lowering future consumption. This would occur when the house hold survival was threatened. In such a case, parents could offer the child as a deal, whereby the parents borrow on behalf of the current household, expecting the child to provide the funds to repay the loan out of the income the child would earn as an educated adult the problem however was the child cannot pre-commit to compensate the parents from future income. Thus, the only option parents have for increasing current household consumption at the expense of the future was either to give the child out for a fee or to put him or her to work. This would transfer the future income to present. A child worked today at the expense of future productivity. Therefore, when children work today, they are denied better living standard in the future since the future income had already been used by the family.

Rajang (2001) also provided theory on market forces as a cause of child labour. Rajang looked at the dynamic implications of market failures as the cause of child at work. Market failure according to Rajang is where there is a failure in the sources of income of parents. According to Rajang, very poor parents would choose education for their children if they had access to a market, but fail to do so because of market failure. Unemployed families produce poor, uneducated children who repeat the cycle for the next generation. The central policy lesson of the Rajang's model is that government intervention is required for only one generation of children. For once, an educated child's income is raised above a threshold level; the newly created parent would be able to choose education rather than child labour for the next generation. This is relevant to the study because in Kete Krachi area unemployment is high which may be the results of poverty in the area and child labour. In addition, the market for agricultural activities is uncertain. Market failures may result in the use of children to raise income.

Although the reduction in poverty can reduce child labour, other areas such as the reduction in family size, employment and parental decision may help to eliminate child labour. Globalization has intensified diseases such as HIV/ AIDS which claims human lives especially adults who double as parents leaving their children as orphans. This prevents these unfortunate children from proper parental care leading to the various ways by which these children resort to, to be able to make a living. Some of this anti-social behavior includes prostitution and child labour. Governance in the country may also compel parents to resort to child labour. If the policies of the government of the day do favour the creation of jobs to enable the people to be employed, it will lead to high rates of unemployment with its antisocial activities such as child labour and the related problems. The people will be jobless and cannot meet their needs because they are not working. Therefore, this called for pragmatic economic policies that will focus on job creation so that, the people will be employed and earned income to be able to educate and feed their children. The above theories serve as the basis for the understanding of the causes and impact as well as ways for eradicating child labour. Models of production can also be a motivating factor that can lead to child labour. Parents rely so much on factors of production to be able to produce to meet their demands. Lack or inadequacy of any of these factors can lead to poverty that can result to child labour. Taken Kete-Krachi area into 
consideration, labour and capital are lacking. Farmers and fishermen at this district find it very difficult to source the needed capital to enable them expand and produce on large scale to be able to feed their families and get some to sell to acquire their basic needs. They also do not have asses to labour to enable them produce on large scale. Because of these factors, they turn to produce only what their strength could do to feed their families. They therefore resort to child labour to be able meet their needs. Most of the writers see child labour as a byproduct of poverty but, poverty is not an independent variable. Child labour may also be caused by socio-cultural and political forces such as unemployment, extended family systems and believes. This work would in addition to poverty, looked at other forces such as socio-cultural and political forces. The practice of polygamous marriage with its high number of children to a family coupled with the acceptance and the practice of the extended family system in the study area allows children to be giving out to other family members for up bring. These children on most occasions are made to work for the up-keep of the home. The activities of these children on most occasions are taken to be child labour because; they are working to supplement the little income of the home. The researcher decided to research into other causes of child labour such as socio-cultural and political forces so as to eradicate and eliminate child labour from the study' area to pave way for better academic performance. The researcher believe that, if child labour is eradicated from the area, it would pave way for better child education leader to the development of the Kete-Krachi area.

\section{Methods}

This chapter discusses the research design, target population and sampling procedure, data collection methods, instruments, validation and reliability of the instruments, data analysis and ethical considerations.

\section{Research design}

The research design for the study was both a descriptive with quantitative and qualitative elements. This is referred to as methodological dualism or triangulation (Kwabia, 2006). The quantitative design helped to produce information that was generalizable (Kwabia, 2006), while the qualitative design helped to produce in-depth information about the subject (Hoepl, 1997). Both quantitative and qualitative designs also produced descriptive and analytical data. The quantitative and qualitative findings complemented one another to add breadth and scope to the results (Schulenberg, 2007). The strengths of each model are also enriched by the weakness of the other. Descriptive quantitative design was used because it involves collection of data in order to test hypotheses or answer questions concerning the current status of the subject of the study. It determines and report's findings the way they are.

\section{Target population}

The target population of the study consisted of 5,581 Junior High school (JHS) students among which 60 victims of child labour were to be selected for the study. Also, the 257 JHS teachers in the schools were targeted among them 60 teachers were to be selected. Also focused were 80 Stakeholders of education, among whom 15 parents and 10 other stakeholders of education were selected.

\section{Sample}

The total sample size for the study was the 145 respondents. These break down to 60 victims of child labour, 60 teachers, 15 parents of the victims and 10 stakeholders. Table 3.1 provides the details.

\begin{tabular}{|c|c|c|c|}
\hline Target Population & Total & Sample Sizes & Sample Method \\
\hline Victims & 5581 & 60 & Tracer \\
\hline Teachers & 257 & 60 & Simple Random \\
\hline Stakeholders of education & 80 & 25 & Convenience \\
\hline TOTAL & 5661 & 145 & \\
\hline
\end{tabular}

The sixty (60) JHS teachers were selected to meet the requirements of a sample survey. Sample survey requires large sample sizes equal to or greater than 40 respondence (Kwabia, 2006), A large sample size was also necessary to take off biases which could arise for sampling fluctuations. A large sample size again could yield data for prediction or generalization. A large number of teachers were also required because of the role teachers' play in the lives of school children (IPEC, 2003). The involvement of large number ofsocial studies teachers was also necessary because their contribution was very vital to the solution of the child labour problem.

\section{Sampling Technique}

The simple random sampling method was used to select the 60 social studies teachers. A list of social studies teachers was obtained from the district education service through the circuit supervisors and the selection was done using random sampling. The simple random sampling helped to obtain sample units across the entire teacher's population. Therefore the simple random sampling method gave all the teachers' equal chance to be selected. With 
the table of random numbers, the list of all the teachers in the district was obtained. Three digits were used since they were more than 100 but less than 1000 . Number which fell below 258 was put into parentheses since the total numbers of teachers in the district 257. Teachers with those numbers selected were included in the sampling unit. The proposed number of victim of child labour were 60 subjects (see table 3.1 ) the selection of this number was difficult because of lack of reliable data or a sample frame of victims of child labour in the area. However, because of the widespread nature of the problem in the area, the researcher was able to reach 60 of such victims. The victims were also considered because they constituted the target group. Their responses were very vital in revealing the various ways to eradicate the problem.

The researcher used the "tracer" method to identify the JHS social studies students who were victims. Tansey (2006) stated that, the tracer method was suitable for gathering qualitative information when there was no sample frame. With this method, the researcher went from school to school to interview headmasters, guidance and counseling coordinators, teachers and students who had identified the victims of child labour. Names which were revealed were traced and questionnaires were distributed to them. Fifteen schools were visited based on the advice of the Assistance Director in charge of supervision in the area. At least one school in the eight circuits in the area was visited and four of the victims were interviewed in each school visited. The schools visited were Osramani JHS, Monkra JHS, Kwakuae JHS, Janjan JHS, Janikrom JHS, Abujuro JHS, Jaisayor JHS, Borae JHS, Bajemese JHS, Banda JHS, Chinderi JHS, Yaborae JHS, Okuma JHS, Wiayi JHS and Okanta JHS. Ten stakeholders were also included in the sample unit. The convenience sampling method was adopted in their selection. That is, the sample units were selected for interviews based on their availability and willingness to take part in the interview (Tansey, 2006) the stakeholders of education selected for the study were mainly circuit supervisors and JHS Headmasters. Table 3.1 shows the target population, sample size chosen from each group and sampling method used to identify the target groups. 15 parents were included in the sample. The involvement of the parents was intended to gather information on family background, causes of child labour and the activity in which the victims are engaged. Interviews could only require a smaller number in order to produce detailed information. This explains why only 15 parents were interviewed.

\section{Research Instruments}

The questionnaire was the main data collection instrument under survey. Two sets of questionnaires were used. One set was for the teachers and the other for the students. This is because these respondents can read and understand the questionnaire to be able to answer them. Apart from their suitability for wider coverage, the questionnaire produced reliable information, helped to interview more respondents, and reduced bias and influence of the researcher. Questions of close-ended where respondents were only given the chance to select either yes or no or open-ended types that is where respondents were given the chance to express their opinion on the issues at stake were used. However, most of the questions were close-ended that is where respondents are given only yes or no options. This was meant to obtain comparable responses and avoid scattering of ideas which could make analysis difficult. The face to face interviews were guided by an interviewer's guide. One set was for the parents and another one for the stakeholders. The interviewer's guide for the parents and stakeholders of education are shown in appendices "C" and "D" respectively.

\section{Procedure for data collection.}

Data collection was done by both survey and face-to-face interviews (personal interview methods). This is a "mixed method" with advantages that the study benefited from (Kirkwood, 2004). The survey research was used to collect data from the teachers. It helped to reach a wider coverage, and minimized variability in the sampling process. The face-to face interview method (personal interview) helped to gather very detailed and accurate information from smaller but well informed respondents (Amoani, 2005). This supports Schulenburg's (2007) observation that, the use of mixed method allows for the presentation of a larger spectrum of divergent views. With the survey, the researcher distributed the questionnaires personally to the teachers and the students in the various schools. He waited and collected the completed questionnaires in order to ensure high return rate. The personal interview method relied on Face-to-face interviews between the researcher and respondents. Five J HS Headmasters were interviewed in the various schools visited in the area while five circuit supervisors were also interviewed at the district education office. Interviews were appropriate for these various groups because their heavy schedules and illiteracy on the parts of the parents prevented them to answer questionnaire. The interview therefore became a handy tool for gathering data from them. Their small number (total of 25) facilitated the use of face-to-face interviews. The researcher recorded the interview responses of the parents, and stakeholders of education into a dairy. The dairy Information made it easy to summaries the responses as well as the time and place of the interviews. The interviews were held under relaxed environment devoid of suspicion. This helped to achieve smooth interview sessions. One month was used for the interviews.

\section{Table 3.2 illustrates the methods and instruments used in the data collection.}

\begin{tabular}{|llll|}
\hline Respondent & Sample & Method of & Instruments Used \\
\hline
\end{tabular}




\begin{tabular}{|lcll|}
\hline Unit & of each unit & Data Collection & \\
\hline Teachers & 60 & Survey & Questionnaire \\
Victims & 60 & Survey & Questionnaire \\
Parents & 15 & Personal Interview & Interviewers Guide \\
Stakeholder of Education & 10 & Personal Interview & Interviewers Guide \\
\hline TOTAL & $\mathbf{1 4 5}$ & & \\
\hline
\end{tabular}

Validity and reliability of instruments

The questionnaire and the interviewer's guide were vetted by lecturers, child labour coordinators and social welfare officers before going to the field. They read through the questions to determine whether their contents were adequate. They also helped to identify any ambiguities. The instruments were later pilot tested at Apedwa using two JHS headmasters, two parents, ten JHS social studies teachers and twenty JHS children. Two schools which were involved in the pilot study were Apedwa R/C JHS and Apedwa Presby JHS Apedwa was used because it has similar physical, social and economic characteristics as the Kete-Krachi area according to the 2000 Population and Housing Census. For example, most of the people in both areas are foodstuff farmers. Suggestions and corrections from the pilot test were used to review the instruments. Responses from the questionnaires and interviews also were cross-checked and compared in order to achieve trust-worthy and valid instruments.

\section{Data Analysis}

The questionnaires were first edited to identify and eliminate errors made by the respondents. This is what Cohen and Manion (1985) recommended before data analysis. The open ended questions were then put into nonoverlapping categories, coded and analyzed. The interview responses were processed like the open-ended questions on the questionnaires. They were then classified into discrete categories, and analyzed using frequency tables, graphs and chart. Descriptive statistics were mainly used because of the nature of the instruments and the responses. The research sought to investigate into the perceptions of impact of child labour on the academic performance of school children in the Kete-Krachi area. All of the 60 of the questionnaires distributed to the teachers were successfully completed and collected. Data were also collected from all the other respondents. Therefore, the analysis was based on 60 teachers, 60 students who are all victims of child labour, 15 parents and 10 stakeholders of JHS education. Data comprismg many items with vast ranges (for example, 95\% as the highest and $1 \%$ as the lowest) were suitably analyzed using tables while graphs were used to analyze mostly "yes" or "no" questions and data with vast ranges. Data with few items of three or more or four were mostly analyzed using pie charts.

\section{Ethical considerations}

As this study utilized human participants, and in the interest of maintaining the integrity of the research, the researcher had made every effort to ensure that certain ethical issues were strictly addressed in respect of the privacy as well as the security of the participants. These issues were identified in advance so as to prevent problems that could arise during the research process. Among the significant issues that were considered included consent, confidentiality and data protectiori. Thus prior to commencing with the research, permission was obtained from each participant, who participated in the study. The names of the participants were secured. The objective, purpose and the significant of the study were all relayed to the participants before initiating the research process. All data collected from the participants were kept in a secure location.

\section{DATA ANALYSIS AND INTERPRETATION OF FINDINGS}

This chapter deals with the analysis and interpretation of data collected from the field. The analysis was done under the personal data, what the authorities should do to eradicate child labour. The respondents were' students, teachers, parents, stakeholders of JHS education (headmasters and circuit supervisors). Compan'son and crosschecking of responses from the victims, the teachers, parents and stakeholders of JHS education were done to see similarities and differences in their responses. 
Personal Data of the Victims

Table 4.1 shows the age of victims respondents. Eighty percent of the victims were within 12-15 age-group. The corresponding male and female ratios were 80.6 percent and 79.2 percent respectively.

\begin{tabular}{|lcccccc|}
\hline Age & \multicolumn{2}{c}{ Male } & \multicolumn{2}{c}{ female } & \multicolumn{2}{c|}{ Both } \\
& ABS & $\mathbf{\%}$ & ABS & \% & ABS & \% \\
\hline Less than 12 & 1 & 2.8 & 1 & 4.2 & 2 & 3.3 \\
$12-15$ & 29 & 80.5 & 19 & 79.1 & 48 & 80 \\
16 and above & 6 & 16.7 & 4 & 16.7 & 10 & 1.7 \\
& & & & & & \\
\hline Total & $\mathbf{3 6}$ & $\mathbf{1 0 0}$ & $\mathbf{2 4}$ & $\mathbf{1 0 0}$ & $\mathbf{6 0}$ & $\mathbf{1 0 0}$ \\
\hline
\end{tabular}

Only 3.3 percent of them were less than 12 years and 16.7 percent were 16 years and above. The age distribution of the students' retlects atypical JHS age group which is usually 12-15 years old. All students interviewed were victims of child labour

\section{Background of the teachers}

The personal data of the teachers indicated that 68 percent of them were males while 32 percent were females, which shows that majority of them were males. Seventy six percent of teachers were 40 years old or younger with only 24 percent being above 40 years. Most of the teachers in the area $(80 \%)$ were on ranks below Principal Superintendent with only 12 percent who were on the rank of Principal Superintendent and above.

\section{Background of stake holders}

Seventy percent of the stakeholders were headmasters while 30 percent were circuit directors. Eighty percent of the stakeholders had been on their position for ten years or below with 20 percent who had been on their position for more than ten years.

\section{Background of parents/ guardian of child laborers}

Responses from the parents indicated that 87 percent of them were illiterates while only 13 percent were literate. Illiteracy on the part of parents might influence them to engage their children in child labour as observed by GSS (2003). Brown, Deardorff and Stern (2001) also observed that, illiterate parents do not appreciate the value of education and as such engage their children in child labour. On marital status, about 67 percent of the parents were married together while 20 percent divorced. Thirteen percent of them were however separated. This implies that 33 percent of the children were under single parenting. On the number of children, 73 percent of the parents or guardians of the children had 5 or more children while 27 percent of them had less than 5 children. Most of the parents or guardians $(87 \%)$ were farmers while only 13 percent of them were engaged in other occupations such as trading and artisan works.

In sum, the background of the children and their parents shows that most of the children were from polygamous families of 5 or more members. Most of the parents/ guardians of the children were illiterate farmers. It was therefore not surprising that children of these parents were mostly engaged in one form of child labour or the other. This is because as observed by Brown, Deardorff and Stern (2001) in their studies elsewhere, children of illiterate parentage and those from polygamous families usually engage in child labour as a result of economic hardship faced by their parents. Illiteracy and polygamous relationships are therefore predisposing factors of child labour (UNICEF, 2000).

\section{Background of victims/ respondents}

Eighty percent of children involved in child labour in the research area fell within 12-15 years with 60 percent of them being males while females accounted for 40 percent. The reason for the male and female difference might be that, much of the work of girls is not often considered as child labour. Domestic services, for example, is a major sector girl-child employment which is not often considered as child labour activities. ILO-IPEC (2001) continued this when it said that child domestic work was largely "invisible" and mostly ignored. Fifty five percent of the victims of child labour in the area were in JHS 2 class that was preparing for the Basic Education Certificate Examination (BECE). Most of them (85\%) started work when they were less than 13 years which is against the 1998 Children's Act of Ghana. Responses from the children indicated that 68 of their parents lived together while 20 percent of their parents had divorced. Sixty eight percent of the fathers of the children had two or more wives and about a third or 32 percent of the fathers had only one wife. This shows that most of the children were from polygamous homes. This agrees with Brown, Deardorff and Stem's (2001) observation that polygamous marriage encourages child labour. Responses from the children also indicated that 92 percent of fathers and 80 percent of mothers were engaged in farming activities 


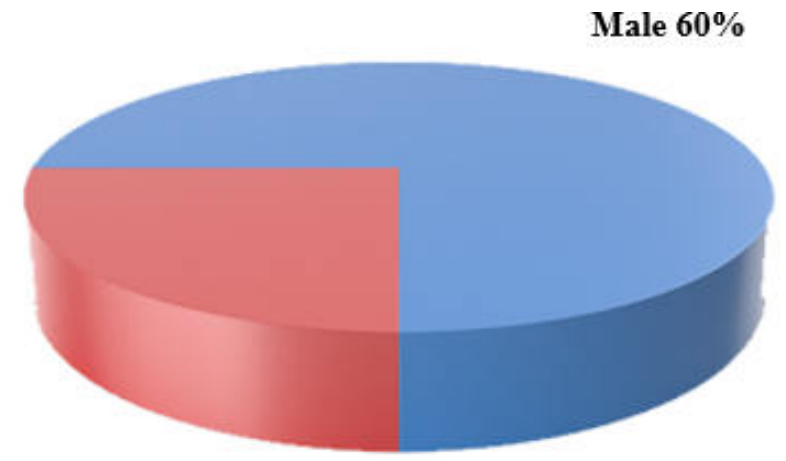

\section{Female $40 \%$}

Fig 4.1 Gender of the Victims.

Sixty percent $(60 \%)$ of them were males while 40 percent were females. This shows that more males than females were victims of child labour in the schools under study. The above result might be influenced by the perception of labour in the area. Some females' work such as domestic activities might not be considered as economic activities and girls engaged in such activities might be ignored as being child labour (IPEC, 2003). Also it may be as results of the transportation of the victims that left out the girls.

The class/ forms of the victims.

\begin{tabular}{|lcccccrr|}
\hline & \multicolumn{2}{c}{ Boys } & \multicolumn{2}{c}{ Girls } & \multicolumn{2}{c|}{ Both } \\
JHS Class /Form & ABS & $\mathbf{\%}$ & ABS & \% & ABS & \% \\
\hline 1. & 16 & 44.4 & 11 & 45.8 & 27 & 45.0 \\
2. & 20 & 56.6 & 13 & 54.2 & 33 & 55.0 \\
\hline Total & $\mathbf{3 6}$ & $\mathbf{1 0 0}$ & $\mathbf{2 4}$ & $\mathbf{1 0 0}$ & $\mathbf{6 0 0}$ & $\mathbf{1 0 0}$ \\
\hline
\end{tabular}

\section{Teachers' personal Data}

Fig 4.2 shows the gender of teachers. In all 68.4 percent males while 31.6 percent were females. The majority of the teachers were males because they form the bulk of teacher's population in public schools in the Krachi area. The age distribution of the teachers is shown in table 4.3. About 56 percent fell within 21-30 age groups with none of them below 20 year

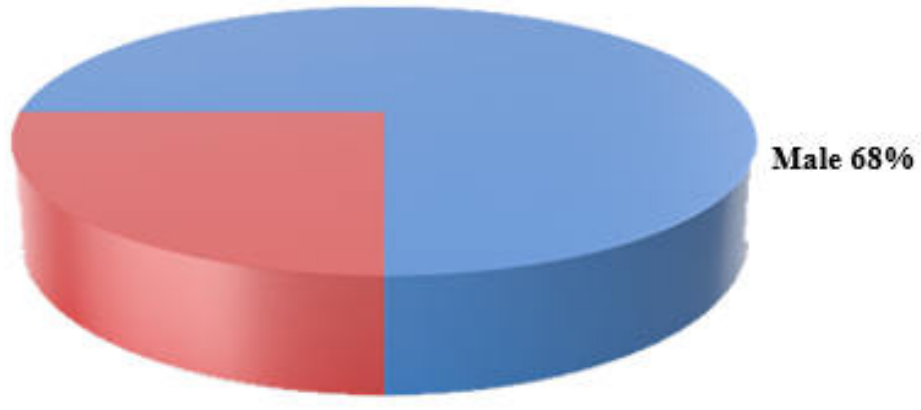

Female 32\%

Fig 4.2 Gender of teachers

The majority of the teachers were males because they form the bulk of teachers' population in public schools in the Kete-Krachi area.

The age distribution of the teachers is shown in T able 4.3. About 56 percent fell within 21-30 age groups with none of them below 20 years.

\begin{tabular}{|lcl|}
\hline Age & ABS & \% \\
\hline Less than 20 & 0 & 0 \\
$21-30$ & 32 & 56.2 \\
$31-40$ & 16 & 29.8 \\
$41-50$ & 9 & 10.5 \\
$51-60$ & 3 & 3.5 \\
\hline Total & $\mathbf{6 0}$ & $\mathbf{1 0 0}$ \\
\hline
\end{tabular}


Three and half percent of the teachers were within the 51-60 age groups. This shows that, the majority 0f the teachers were relatively young. The rank or position of the social studies teachers is displayed in table 4.4. Petty one percent of the teachers were within the lower ranks, that is, the rank of superintendent 1 or below.

Rank/position of teachers

\begin{tabular}{|lcc|}
\hline \multicolumn{1}{|c|}{ Rank/ position } & ABS & $\mathbf{\%}$ \\
\hline Pupil teacher & 8 & 14.0 \\
Superintendent II & 13 & 22.8 \\
Superintendent I & 8 & 14.0 \\
Senior Superintendent II & 11 & 21.0 \\
Senior Superintendent I & 9 & 15.8 \\
Principal Superintendent & 5 & 8.8 \\
Assistant Director II & 2 & 1.8 \\
Assistant Director I & 2 & 1.8 \\
\hline Total & $\mathbf{6 0}$ & $\mathbf{1 0 0}$ \\
\hline
\end{tabular}

About 3.8 percent were with the higher ranks of Assistant Director 11 Assistant Director 1 while 45.6 percent were in between the lowest ranks (Superintendent 1 and below) and the highest ranks (Assistant Directors grade). 4.2.3 Characteristics of Stakeholders of JHS Education

All the stakeholders interviewed were males with 70 percent of them being headmasters and 30 percent of them being circuit supervisors.

Fig 4.3 shows the number of years that stakeholders of JHS education have been on their position

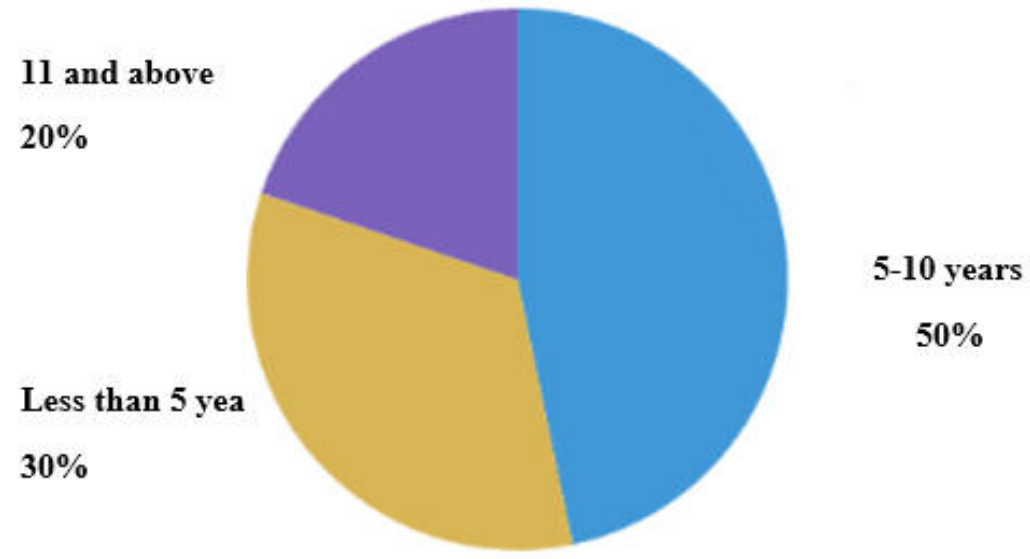

Fig 4.3 Number of years Stakeholders had been on their position

Half of them $(50 \%)$ have been on their position for 510 years and few of them $(20 \%)$ have been on their position for more than 11 years.

\section{WAYS TO ERADICATE CHILD LABOUR}

One of the main objectives of the research was to provide recommendations on how child labour can be reduced or eradicated. Views were sought from the respondents on how to address child labour. Fig 4.18 shows the responses of the victims on what social studies teachers and their parents should do to create the necessary awareness and help solve child labour. About 97 percent of the victims said their parents should pay their school fees while 98.3 percent admitted that their parents provide them all their educational materials. They also agreed that their social studies teachers should teach about child labour and its effects to School children.

\section{Ways to eradicate Child Labour}




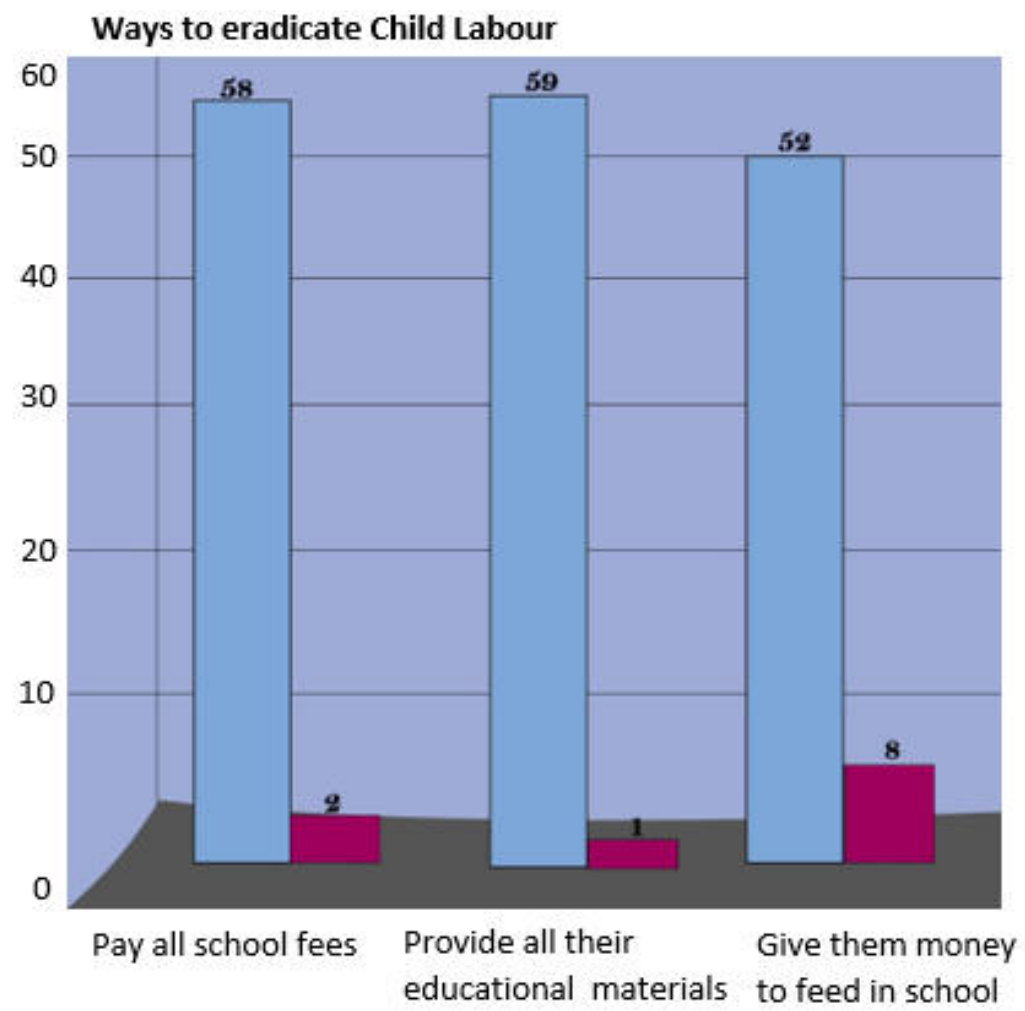

Fig 4. 18: Responses of victims on what parents should do to eradicate Child labour.

In addition, 86.7 percent also agreed that their parents should give them money to feed themselves in school. This implies that, the children wanted their parents to be educated on their responsibilities in providing their needs such as pay all their school fees, provide them all the educational materials to stop them from working.

Twa a form one student of LA J HS also remarked;

I know it is the responsibilities of my parents to provide all my educational needs but I cannot tell them. I believe you can tell them for me. (F ield interview, April, 2018)

Another form two student Jak of LA JHS also remarked' our social studies teachers should teach us more on the dangers of the work we are doing. They should also educate our parents on the effect of the work we are doing so that we can stop working and only go to school to learn. (Field interview, April, 2018) The above response of the victims shows that, they want to stop working and concentrate on their schooling and nothing else. The responses of the social studies teachers on what parents should do to eliminate child labour are summarized in Table 4.23.

\section{Table 4. 23: Teachers Responses on what parents should do to Eliminate Child labour}

\section{The role of parents}

Send and keep their children in school

ABS

Provide educational needs of their children in child labour

Desist from engaging their children in child labour

60

Yes

Cooperate with efforts to eliminate child labour

100

The table Shows that all the teachers wanted p

60

educational needs of the children, desist from giving their children out for labour and cooperate with efforts to eliminate child labour. The parent should also be educated on the effects of child labour on the education of their children.

Oman a female teacher of LA J HS also remarked;

it is time we tell these parents it is their responsibility to send and keep these children in school and provide all their needs but not the children working. (Field interview, April, 2018)

Ras a teacher of Presby JHS also remarked;

we as teachers have a big task on hand, that is educating these parents on their role as parent in the education of their Children. We have to organize educational campaigns on the effects of child labour on the children's education for the parents regularly. (Field interview, April, 2018)

The above statements from the social studies teachers signifies that as social studies teachers, they acknowledge the fact that they need to educate the parents on their role as parents to promote the education of their 
children. ILO (2004) and IPEC (2003) noted that parents have an important role to play towards the elimination of child labour. ILO (2004) similarly stated that parents must support and get involved in their efforts to eliminate child labour among children.

Responses from the social studies teachers on the role they play towards the creation of the awareness and the elimination of child labour are shown in Table 4.24. The table shows that 91.2 percent also said that they create awareness and advised victims during social studies lessons on the impact while 93 percent also said that they advised parents on the impact.

\begin{tabular}{|c|c|c|c|c|c|c|}
\hline \multirow[b]{2}{*}{$\begin{array}{l}\text { The role of Teachers } \\
\%\end{array}$} & \multicolumn{2}{|c|}{ Males } & \multirow{2}{*}{$\begin{array}{r}\text { Females } \\
\text { ABS }\end{array}$} & \multirow[b]{2}{*}{$\%$} & \multicolumn{2}{|c|}{ Totals } \\
\hline & ABS & $\%$ & & & & ABS \\
\hline Advising victims on the impact & 52 & 91.2 & 5 & 8.8 & 60 & 100 \\
\hline Advising parents on the impact & 53 & 93.0 & 4 & 7.0 & 60 & 100 \\
\hline Organizing awareness campaign & 22 & 38.6 & 35 & 61.4 & 60 & 100 \\
\hline Reporting the perpetrators to the police & 2 & 3.5 & 55 & 96.5 & 60 & 100 \\
\hline
\end{tabular}

However, 61.4 percent and 96.5 percent of the social studies teachers said they did not organize awareness campaign or report the perpetrators of child labour to the police respectively but they created the awareness during social studies lessons. Teachers do not see awareness creation as their role as observed by IPEC (2003) when they stated that teachers can disseminate information on child labour and organize awareness creating campaign. IPEC (2003) further stated that teachers as part of their regular work use formal and informal mechanisms to identify, prevent and track child labour practices. In addition, the teachers do not see reporting the perpetrators of child labour to the police as their role. It is necessary to give the teachers the mandate to report perpetrators to the police since they are the first to be blamed on the educational impacts of child labour. Fig. 4.19 shows the responses from the teachers on what opinion leaders could do to eliminate child labour.

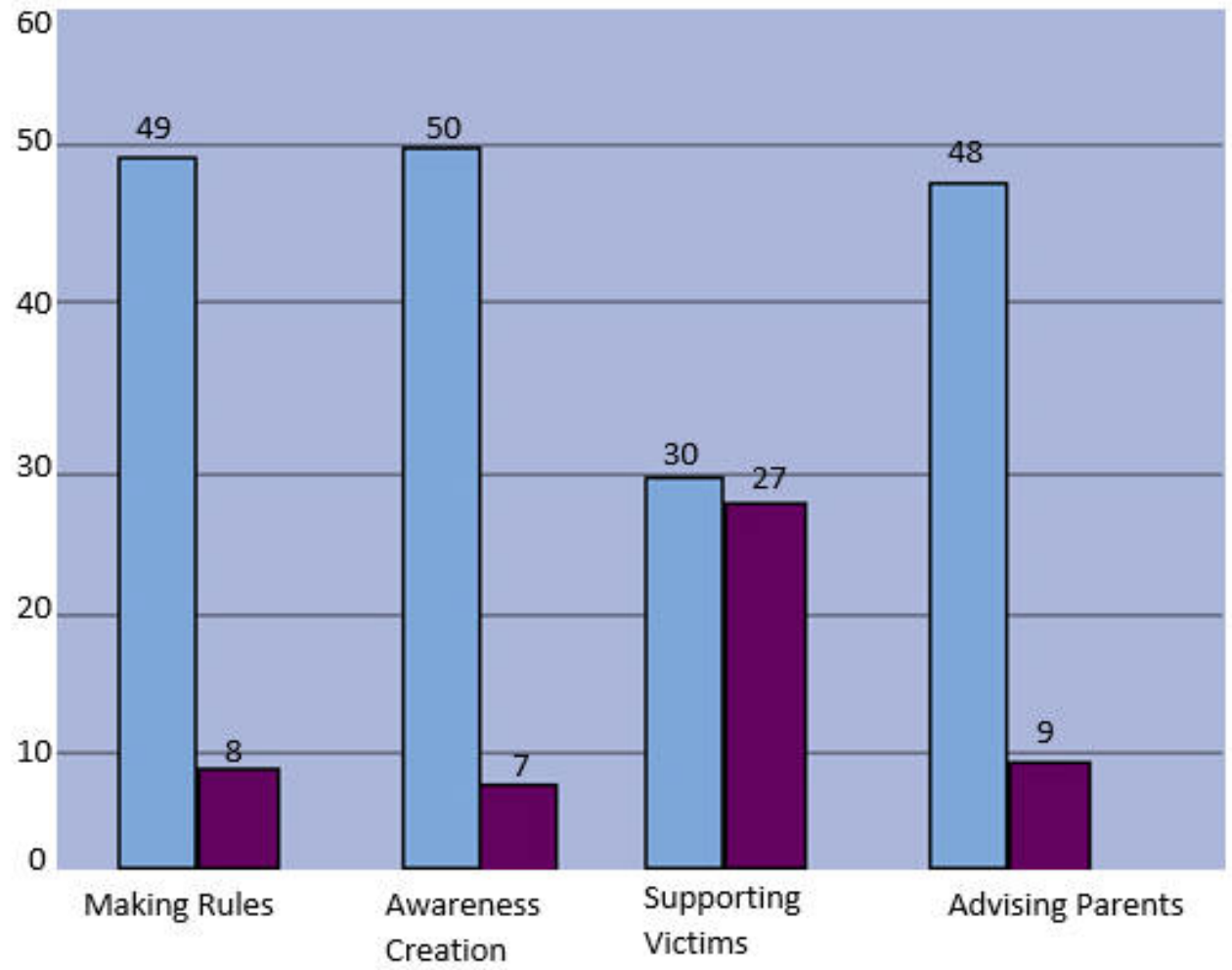

FIG.4.19: The Role the Opinion Leaders towards Eradication of Child Labour.

Most of the social studies teachers answered in affirmative on the role of the opinion leaders to eradicate child labour. The "Yes response" to the various items includes making rules on child trafficking (84.2\%), awareness creation (87.7\%), supporting victims (52.6\%) and advising parents (84.2\%). Apart from supporting victims (47.4\%), less than 20 percent disagreed on the various items as the roles of opinion leaders. On the role of the opinion leaders, African Recovery (200]) tasked community leaders to educate parents and guardians on the dangers of child labour. The research inquired about the role NGOs play towards the eradication of child labour 
in the area. Table 4.25 summarizes the responses from the social studies teachers on the role of NGOs towards the eradication of child labour.

Ofo a teacher of Methodist J HS remarked;

the chief of this area has every right to put in place by-laws against child labour in this area, to stop the growing menace of child labour. (Field interview, April,2018)

Vic a teacher of SDA JHS also remarked;

we must team up with the chief and elders and the opinion leaders of this community to help eradicate child labour. (Field interview, April, 2018)

The above statements made by the social studies teachers' shows that they were prepared to work with the opinion leaders in the area to eradicate child labour.

Table 4.25: The Role of NGOs towards Elimination of Child Labour

\begin{tabular}{|lcccccc|}
\hline The Role of NGOs & \multicolumn{2}{c}{ Yes, } & \multicolumn{2}{c}{ No } & \multicolumn{2}{c|}{ Total } \\
& ABS & \% & ABS & \% & ABS & \% \\
\hline Awareness Creation & 82 & 91.2 & 5 & 8.8 & 60 & 100 \\
Providing financial assistance to parents & 46 & 80.7 & 11 & 19.3 & 60 & 100 \\
Provision of educational needs of the Children & 53 & 93.0 & 4 & 7.0 & 60 & 100 \\
Research into the problem of child labour & 48 & 84.2 & 9 & 15.8 & 60 & 100 \\
\hline
\end{tabular}

The positive responses from most of the social studies teachers on the various items show that the NGOs have major roles to play towards the elimination of child labour in the area. Those who answered in affirmative include; awareness creation $(91.2 \%)$, providing financial assistance to the presents $(80.7 \%)$ provision of educational needs of the victims $(93.0 \%)$ and research into the problem of child. labour $(84.2 \%)$. The "No response" ranges from 7.0 percent for provision of educational needs of the victims of the children to 19.3 percent for providing financial assistance to parents. The positive responses from the social studies teachers on the role of the NGOs agree with IPEC (2003) when they enjoined NGOs to implement pragmatic programmes to provide direct support for children, raise awareness and mobilize society to take action against child labour. The responses from the social studies teachers on the role of the district assembly towards the elimination of child labour are shown in table 4.26. Ama a teacher of LA JHS indicated;

The NGOs in this area can also create the awareness by displaying pictures on the effects of child labour on children's education at vantage places in this area to educate both parents and passersby. (Field interview, May, 2018)

The Role of the District Assembly towards the Eradication of Child Labour

\begin{tabular}{|lcccccc|}
\hline The role of the District Assembly & \multicolumn{2}{c}{ Yes, } & \multicolumn{2}{c}{ No } & \multicolumn{2}{c|}{ Total } \\
& ABS & $\mathbf{\%}$ & ABS & $\mathbf{\%}$ & ABS & \% \\
\hline Enactment of by-laws & 52 & 91.2 & 5 & 8.8 & 60 & 100 \\
Organizing awareness campaign & 46 & 80.7 & 11 & 19.3 & 60 & 100 \\
Provision of educational Needs & 53 & 93.0 & 4 & 7.0 & 60 & 100 \\
Providing financial assistance to Parents & 48 & 84.2 & 9 & 15.8 & 60 & 100 \\
\hline
\end{tabular}

Those who answered in affirmative to the various items include enactment of bye-laws (91.2\%) organizing awareness campaign (94.7\%). Others are provision of educational needs $(91.2 \%)$ and providing financial assistance to parents $(84.2 \%)$. The positive responses from the social studies teachers imply that such roles were expected by the social studies teachers to be played by the district assembly towards the eradication of child trafficking.

The responses from the children on what government should do to prevent children from working are recorded in Table 4.27.

Oma a teacher of Presby J HS also remarked;

to help eradicate child labour in this area I believe if the District Assembly can also give financial assistance to the parents and also award scholarship to needy but brilliant children it would also help. (Field interview, May, 2018) This goes to confirm the fact that the role of the District Assembly to eradicate child labour cannot be over emphasized in the area.

The Role of Government towards the Eradication of Child Labour

\begin{tabular}{|lcccccc|}
\hline The role of Government & \multicolumn{2}{c}{ Yes, } & \multicolumn{2}{c}{ No } & \multicolumn{3}{c|}{ Total } \\
& ABS & $\mathbf{\%}$ & ABS & \% & ABS & \% \\
\hline Make education free by absorbing all fees & 59 & 98.3 & 1 & 1.7 & 60 & 100 \\
Providing educational materials & 58 & 96.7 & 2 & 3.3 & 60 & 100 \\
Feed the student while in school & 57 & 95 & 3 & 5.0 & 60 & 100 \\
\hline
\end{tabular}

In all, 98.3 percent said government should make education free by absorbing all fees, 96.7 percent also said 
government should provide all the educational materials while 95.0 percent also said government should feed them while at school. Most of them therefore agreed that government should perform those roles to solve the problem of working children. The government therefore has a major role to play to solve the problem of child labour. The government must implement fully the free compulsory basic education programme and the school feeding programme. In addition, the government must be more committed to the education of the vulnerable by providing them with all their educational needs as these could help to address child labour. Responses from parents on what should be done to address child labour shows that, they wanted the government to provide the children their educational needs and absorb all fees.

A parent and a yam farmer Mow also remarked;

They say education is free but it is not free. They go round saying that we don't pay school fees. This is not true. The only thing is that the fee has been reduced. If education is really free, it would help us, (Field interview, May, 2018)

Another parent and a fisherman also remarked;

We were told education is free, yet they kept collecting money from us now and then. We better prepared to pay for everything. (Field interview, May, 2018)

These statements from the parents show that they want education to be free and not free to some extent as it stands today.

The responses from the teachers on how social studies are creating the awareness of child trafficking and helping solve the problem in the area are shown in Table 4.28. About 80 percent of the social studies teachers said social studies is creating the awareness but the awareness is not enough. About 58 percent of the social studies teachers said the best way to create awareness and help solve the problem is the social studies curriculum. 20 percent of them said the curriculum is silent on child labour. The responses from the social studies teachers suggest that, to them the social studies curricula is the best tool to help create the awareness of child labour and help solve the problem of child labour. They suggest that, more emphasis should be put on the causes and effect of child trafficking in the syllabus to give more time to the social studies teacher to help create the awareness of the problem among school children and help solve it.

Teacher's Response on how to Eradicate Child Labour

\begin{tabular}{|lcc|}
\hline Mechanism & ABS & $\mathbf{\%}$ \\
\hline Social studies awareness not enough & 33 & 58.9 \\
Curriculum is silent & 15 & 20.3 \\
More research by teachers to find solution to the problem & 0 & 0 \\
More topic on child trafficking in syllabus & 7 & 10.5 \\
More textbooks should be written on problem & 5 & 5.3 \\
\hline Total & $\mathbf{6 0}$ & $\mathbf{1 0 0}$ \\
\hline
\end{tabular}

None Of the 500131 Studies teachers saw more research by the teachers to find solution to child labour. The curriculum designers should design the social studies Syllabus to give more attention to child labour.

Olhe a teacher of LA J HS said;

more topics on the causes and effects of child labour should be added to the social studies syllabi so that the awareness creation would be started from the schools, because it is the schools that deals with the future leaders and social studies is one of the important subjects that deals with problem solving of man. (Field interview, May, 2018)

Opow teacher of SDA J HS said;

the District Educational Oversight Committee should be working with social studies teachers to be organizing awareness creation in the area to sensitize the general public on the dangers and effects of child labour on children's education. (Field interview, May, 2018)

Jou a teacher of Presby J HS also remarked;

more textbooks should be written on the dangers and effects of child labour on children's education. I believe when children read and see the effects of the work they are doing, they would also advice their parents on the dangers of child labour. (Field interview, May, 2018)

The statements made by these teachers should tell CRDD of the Ghana Education Service of their role of introducing more topics on child labour in the social studies syllabi to help eradicate child labour. 


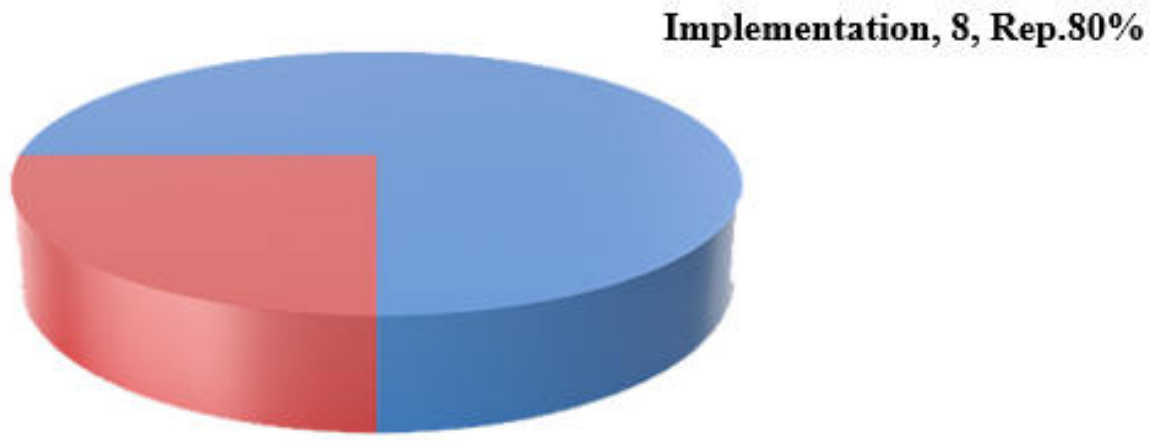

Public education, 2, Rep. 20\%

Fig. 4.20: Stakeholders' Responses on the Best Mechanism to Address Child Labour

Fig 4.20 shows the responses of the stake holders of education on the ways to address child labour. Most of them $(80 \%)$ said the best way to address the problem of child labour is public education in schools and outside school while 20 percent of them said the best way to address child labour is implementation of laws. The responses from the social studies teachers and the stakeholders of education suggest that, to them awareness creation through public education in schools and outside the school is the best way to solve child labour in the area and government and NGOs and civil society organizations should pull resources together to educate parents on the dangers Of Child labour (ILO, 2004).

Born a supervisor indicated;

the best way to address child labour in this area is the various stake holders in education including Ghana Education Service, NGOs, Opinion leaders and the rest to engaged in serious public education on the causes and effect of child labour to sensitize the general public on the short and long effect of this serious problem. (Field interview, May, 2018)

Ba a teacher of LA JHS also said;

I believe incorporation of topics on child labour into the educational curricula would also help to eradicate child labour. Subjects such as social studies could be used to sensitize the future leaders about the causes and the effects of child labour. (Field interview, May, 2018)

These statements of the stakeholders of education in the area also confirm the appeal made by the teachers to the CRDD on the introduction of more topics on child labour into the social studies syllabi.

Another head teacher also indicated;

Enacting and enforcement of child labour laws by the chiefs and on leaders in the area may be one of the best ways to eradicate child from the area. (Field interview, May, 2018)

I believe all stake holders of education in the Krachi area and Ghana as a whole would take this advice and take measures on it.

\section{SUMMARY OF FINDINGS, CONCLUSIONS AND RECOMMENDATIONS}

The paper sought to investigate the various mechanisms to eradicate the problem of child labour in the Kete-Krachi area of the Oti Region. To achieve these objectives, data were collected from 145 respondents comprising 60 teachers, 60 victims, 15 parents and 10 stakeholders of education. The survey method and questionnaire instrument were used to collect data from victims and the teachers while personal interviews were used to gather data from the parents and stakeholders. The data were analyzed and interpreted using frequency tables, graphs and charts. The major findings of the study are summarized on the mechanism to eradicate child labour in the area. Conclusions are drawn.

\section{Mechanisms to Rradicate Child Labour}

The children wanted their parents to perform certain basic parental roles for them to stop working. Ninety percent said their parents should pay all their fees while 98 percent said their parents should provide them with all their educational materials. In addition, 87 percent said their parents should give them money to feed themselves in school. The social studies teachers also indicated certain roles which parents were to perform to eliminate child labour in the area. All of them indicated that parents should send and keep their children in school, provide the children with their educational needs, desist from engaging their children in Child labour and cooperate with efforts to eliminate child labour. It can be concluded that, the full upbringing of the child is a natural responsibility of a parent or a guardian. 
As noted by the teachers and the children, parents or guardians need to perform certain roles towards the full development of their children. They should send and keep their children in school by providing them all basic educational needs. Laws and policies could be made on child labour but they could only be successful if parents or guardians who engaged their children in child labour are agreeable to them. ILO (2004) therefore advised parents to support and get involved in efforts to eliminate child labour. The social studies teachers indicated some of the roles they played towards the elimination of child labour. Ninety one percent said they advised victims on the impact while 93 percent said they advised parents on the impact. However, 61 percent said they did not organize awareness campaign on the problem of child labour. It must however be noted that in addition to advice teachers gave on impacts of child labour to the children and their parents, they need to organize awareness campaign on the problem in their various communities. IPEC (2003) has noted that teachers can disseminate information on child labour during their social studies lessons and organize awareness Campaign on the impact of the problem in their various communities to eliminate child labour. The teachers also indicated some roles to be played by Opinion leaders such as chiefs. Town Development Committees (TDC) leaders and Assembly members towards the elimination of child labour. Eighty four percent of them said opinion leaders make rules on child labour while 88 percent said they should organize awareness creation. In addition, 84 percent said the opinion leaders should advice parents on the impact while about half (53\%) indicated that the opinion leaders should support the victims. It can be concluded that, opinion leaders have a major role to play in the fight against child labour. As community leaders, they should advice parents to desist from engaging their children in child labour. They could also support victims, make rules on child labour and create awareness on the impact of child labour. It is in this direction that Africa recovery (2001) tasked community leaders to educate parents and guardians on the dangers of child labour. The teachers also indicated certain roles to be played by NGOS towards the elimination of child labour. Ninety one of them said the NGOS should undertake programmes to create awareness while 81 percent indicated that, the NGOS should provide financial assistance to parents. In addition, 93 percent said NGOs should provide educational needs of the children while 84 percent said the NGOS should undertake research into the problem of the child labour. They should contribute towards the solution of the problem through awareness creation, research into the problem, provision of educational needs of the victims and provision of financial assistance to parents and guardians of Victims. It is on this basis that IPEC (2003) enjoined NGOS to implement programmes to provide direct support for children, raise awareness and mobilize society to take action against child labour.

There are certain roles which the district assembly is supposed to play as indicated by the social studies teachers towards the elimination of child labour. Ninety one percent said the district should enact bye-laws on child labour while 95 percent were of the view that the district assembly should provide educational needs of the victims as well as organizing awareness campaign. While 84 percent said the district assembly should provide financial assistance to parents of victims. It can be concluded that, the district assembly as the highest policy making body in the district should enact bye-laws, provide the basic educational needs of children and intensify awareness campaigns on child labour. The responses of the children indicated that, they wanted government to perform certain roles in order to stop working. Ninety eight percent of the children said they wanted g0vernment to make education free by adsorbing all fees while 97 percent and 95 percent said the government should provide all the educational materials and feed them while in school respectively. Responses from the parents also indicated that, they wanted the government to absorb all school fees of the children and provide the necessary educational needs of the children. It can be concluded that the government should absorb all school fees, provide the necessary educational needs of the children and make the school feeding programmed to cover the entire nation in order to eliminate child labour. There would be the need therefore to increase the capitation grant and the amount meant for the school feeding programmed, In addition, government must address the problem facing quality education at the basic level. On how social studies is creating the awareness and helping to solve the problem of child labour, 95 percent of the teachers; said more topics on child labour should be introduced into the social studies syllabus to help make the subject look more problem solving. 5 percent of the social studies teachers said the Ghana education service should organize more workshops for teachers on the nature of social studies today to help them educate the future leaders on problems such as child labour. One can therefore conclude that, for social studies being problem solving oriented, to help create the awareness of the problem and help solve child labour, the social studies syllabus should be drawn to cover more topics on child labour and the related problems that affect the survival of mankind. There should be more workshops on the teaching of the subject.

\section{Recommendations}

Recommendations have been made based on the issues derived from the major findings and conclusions from the ways to eradicate child labour. These recommendations are geared towards addressing the issue of child labour in school children in the Kete-Krachi area. The recommendations might benefit school children in child labour elsewhere in Ghana as well as policy makers.

\section{What the authorities should do to eliminate child labour.}


It was concluded that the various authorities in the area has 21 major role to play to eliminate child labour. The authorities in the area such as chiefs, district assembly, NGOs and those who have interest in child education should support effort to eliminate the problem. The chiefs and district assembly should enact bye laws that would see to the non-existence of child labour in the area.

\section{REFERENCES}

Abdula. (2007 May 4) 6.3 Million Engaged in Child Labour. Daily Graphic p. 31. African Chapter on the Rights and Welfare of the Child (1990) Retrieved on 5/2/10 http://www//.umn.edu/humanrts/africa/afchild. htm.

Africa Recovery (2001). Protecting African's Children. In UN Department of Public Information Vol. 15 (3) (October 2001). (P.14-16)

Africa Recovery (2004). Protecting African's child from child labour. In UN Department of public Information V01. 16 (4) November 2004). (P16-19).

Alonge, M.F. (1989). Measurement and Evaluation in Education and Psychology. Ekiti: Adedayo Publishing.

Amoani, F. K. (2005). Introduction to Research Methodology: An Overview. Accra; Pentecost Press Ltd.

Antwi, M. K. (1992). Education, Society and Development in Ghana. Accra: Unimax Ltd.

Appiah, A. K \& Flolu J . (2006). Human Rights in Conception: Concepts Andprinciples In Awoyemi, M \& Flolu, J . Eds., Introduction to Human Rights Education

Accra: Black Mask Limited, p. 59-76.

Akordor, K.(2007 June 27). The child Labour Debate. Daily Graphic (Accra), P-7

Bell, J. (1993). Doing Your Research Project. A Guide for First Time Researcher in Education and Social Science (2nd Ed.). USA: Buckingham Open University Press.

Brown, D.K., Deardorff, A. V. \& Stern, R.M. (2001). Child Labour, Evidence and Policy. Chicago University of Chicago Press.

Canagarajah, S. \& Conlombe, H.(1993). Child Trafficking and Schooling in Ghana. Retrieved on 5/2/2010 http://www//wb/n001 8 .worldbank.org/ htm/dec/publiccations/workpapers/Wps

Corrigan, P. (1990). Social Forms/ Human Capacities: Essays in Authority and Difference. London: Rutledge.

Cohen, L. \& Manion L. (1985). Research Methods in Education (2“d ed.). London: Croom Helm Ltd.

Convention on the Rights of the Child (1989). Retrieved on 18/2/2010 http://www.ymnedu/humanrts.insteel/k2erc.htm

Declaration of the Rights of the Child (1959). Retrieved on 12/02/10 http://www/.umn.edu.hmnanrts.instreel/k/drc.htm

Dodnnellan, C. (2002). Child Labour. England: Independence Educational Publishers Cambridge.

DFID (2000).Education for:The Challenge Of Universal Primary Education. London: Department for International Development

Dowuona, D (2007 June 27) Children in Commercial Agriculture: A Necessary Evil? Daily Graphic (Accra), p.7.

Dzamboe, T. \& Agave G. (July 19, 2008). More Chiidren Engaged In Hazardous Work. The Mirror, p.35

Edmonds, E-V\& Pavenik, N. (2004). International Trade and Child Trafficking: Cross Country Evidence: Dartmouth College.

Fraenkel, J . \& Wallen, N. (2003). How to Design and Evaluate Research in Education (3rd ed.)New York: McGraw-Hill Inc.

Ghana Statistical Service (2003). Ghana Child Trafficking Survey. Accra: Ghana Statistical Service.

Global Watch International Secretariat (2004). Retrieved on 10/11/2009 httpzllwww.ghanaweb.com/Ghanaomepage.

GNA ( 2007, March 13). Girl-Enrolmem in Kete-Krachi District is still low: Retrieved on 10/11/2009 http://www.ghanaweb.com/Ghanahomepage regional/artikel.php.

GNCC (1997). State of the Child Report: Kete-Krachi District, Volta Region. Accra: Ghana National Commission on Children.

GNCC (2002). Ghana 's Children: The'Child's perspective. Accra: Ghana National Commission on Children.

Hoepl, M. C. (1997). Choosing Qualitative Research: A Primer for Technology Education Researches. 1n Journal of Technology 9 (1) Retrieved 16/4/07 http:1/scholar.lib.vt.ejournals.JTE.v9n1/hoepfl.html.

ILO Convention 182 (1999). A New Tool to Combat the Worst Form of Child Labour. Geneva: ILO.

ILO-IPEC (2001). Child Labour: A Textbook for University Students. Geneva: International Labour Organisation.

ILO-IPEC (2006). ILO-IPEC Interregional Workshop on Child Domestic Labour and Trade Unions Report. Geneva: 1L0

1L0 (2004). Child Labour: A Textbook for University Students. Geneva: International Labour Organisation 1PEC.(2003). Combating Child Trafficking through Education, Geneva: ILO

Jean-Marie, B. \& Robinson, J . A, (2002). "Is child Labour inefficient" Journal of Political Economy 8 (4) pp. 662-679.

Jensen, P. \& Neilsen, H. S. (1997). Child Labour or School Attendance? Evidence From Zambia In Journal of 
Population Economics volume 10 pp. 407-424

Kelsey, S. \& Peterson, B. (2003). Human Rights: Handbooks for Ghanaian Journalists. Accra: Journalists for Human Rights (JHR)

Kim, J . Zepeda, I \& Kantor, P. (2005). Child Labour Supply on US Family Farms: An Interdisciplinary Conceptualization In Journal of Family and ECONOMiC Issues p. 159-172.

KirkwoodTucker, T. F. (2004). Empowering Teachers to Create a more Peaceful World through Global Education: Simulating the United Nations In Theory and Research in Social Education 32 (1), p. 56-74.

Kete-Krachi District Assembly (2006). Third Medium Term Development Plan (2009 201 1). Kete-Krachi District Assembly

Kwabia, K. (2006). Element of Social Statistics .Accra: Woeli Publishing Services.

Kwabia, K. (2006). Theory in Social Research: The Link between Literature And Observation. Accra: Woeli Publishing Services.

Lamptey, A. (2001 , November 8). The Causes and Effects of Child-Abuse. Daily Graphic. p.9

Mensah-Bonsu, H.J.A.N. \& Dowuona-Hammond, C. (1994). The Rights ofthe Child In Ghana Perspectives. Accra: Woeli Publishing Services.

Merges, G. J. (1992, November 2). The Economic Contributions of Children in peasant Agriculture and the Effect of Education: Evidence from the Philippines in Pakistan Development Review. Volume 31, p189-201

Ministry of Education, (2003). Teaching Syllabus for Social Studies (Senior Secondary School). Accra: CRDD.

Odumah, L. (2003). Foundations of Social Studies. Accra: Jospong Printing Press.

Patrinos, H. A. \& Psacharopoulas, G. (1997, November 4). Family Size, Schooling, and Child Labour In Peru: An Empirical Analysis In Journal of Population Economic, Volume 10, p. 387-405.

Ranjang, L. (200]). Dynamic Implicalions of Market Failure as a Source of Child Labour. Chicago: University of Chicago Press.

Republic of Ghana (1992). 1992 Constitution of the Republic of Ghana.

Republic of Ghana (1 992). SummaryThe Child cannot wait: A National Programme Of Action on the follow up to the World Summit for Children.

Republic of Ghana (1999). Children's Act, 1998.

Santrock, J . (2005). A Tropical Approach to Life-Span Development. New York McGraw Hill.

Schulenberg, J . L. (2007). Analyzing Police Decision-Making: Assessing the Application or Mixed Method/Mixed Model Research Design In Brennen. J. and Rosalind, E (ED) International Journal of Social Research Methodology: Theory \& Practice, London: Taylor \& Francis Vol. 10 No.2 p.99-119

Tansey O. (2006). Processing Tracing and Elite Interviewing: A Case for Non Probability Sampling. Retrieved 6/7/09 http://www.asu.edu/clas/polisci./aqrm/APSA.2006. /Tansey-processing-Tracing.

UN Convention on the Right of the Child (1989). Retrieved 12/4/09http://www.iol.orgl

UNESCO (2000). World Education Forum. The Dakar Framework for Action: Education for All (2000) 26-28 April, pp. 15-75.

UNICEF (1996). The State of the World's Children. Oxford: Oxford University Press.

UNICEF (2000 March, 5). Poverty Reduction Begins with Children. New York: UNICEF.

UNICEF (2000 October, 10). What is the effect of Child Labour on Learning Achievement? Evidence from Ghana. New York: UNICEF

UNICEF (2002) A World Fit for Children . New York: UNICEF

UNICEF (2004). The State of the World's Children 2005: Childhood under Threat, New York: UNICEF.

Volta Region (2007)' Executive Summary on Economic and Social Characteristics of the Volta Region Retrieved 10/4/09 http://www.modernghana.com/GhanaHome/regions/volta.asp?-id=68.submenu=id=1338

World Book Encyclopedia, Volume 3 (1992). World Book Inc.

Zaney G B (2001 January 29). Child Trafficking in Ghana Towards Eventual Elimination. The Ghanaian Times Accra: p.6 